Western University Scholarship@Western

1996

\title{
Notes on the Microfoundations of Monetary Economics
}

David Laidler

Follow this and additional works at: https://ir.lib.uwo.ca/economicsresrpt

Part of the Economics Commons

Citation of this paper:

Laidler, David. "Notes on the Microfoundations of Monetary Economics." Department of Economics Research Reports, 9610. London, ON: Department of Economics, University of Western Ontario (1996). 


\title{
45908
}

ISSN:0318-725X

ISBN:0-7714-1930-9

\section{RESEARCH REPORT 9610}

\author{
Notes on the Microfoundations of Monetary Economics \\ by \\ David Laidler
}

October 1996

\author{
Department of Economics \\ Social Science Centre \\ University of Western Ontario \\ London, Ontario, Canada \\ N6A 5C2 \\ econref@sscl.uwo.ca
}


Notes on the Microfoundations of Monetary Economics*

by

\author{
David Laidler \\ The University of Western Ontario
}

' * Paper prepared for a forthcoming Economic Journal Symposium. 


\section{INTRODUCTION}

It is important to keep two closely related distinctions in mind when discussing the microeconomics of money: that between the social arrangement known as monetary exchange, and those assets known as money; and that between what Patinkin (1957) called the market experiment and the individual experiment.

\section{MONEY'S FUNCTIONS}

Money is a means of exchange. a unit of account, and a store of value, though many items that do not serve as means of exchange make admirable stores of value. while it is also possible to have prices stated and accounts kept in terms of units of something other than the economy's means of exchange. Thus the means of exchange function is the sine qua non of money, and a satisfactory micro-economic foundation for the study of monetary phenomena mist therefore be grounded in the analysis of a market rather than an individual experiment.

In microeconomics we usually begin with the study of the choices facing an individual agent considered in isolation, go on to discuss the properties of such a "Robinson Crusoe" or "representative agent" economy, and proceed. by way of aggregation over such agents. to an array of market supply and demand equations which we solve for the multi-agent economy's equilibrium.

We cannot, however, build up a theory to deal with an economy-wide demand for a means of exchange in this way. Crusoe interacts with nature (technology and endowments) to solve his economic problem, but there is no market exchange in a one agent economy. This becomes possible, and gains from trade open up, with the arrival of Friday, but in a two person economy barter is an efficient trading method. 
Monetary exchange involves the systematic appearance on one side of every trade of a particular item which is offered and accepted, not for the sake of its own intrinsic properties as a consumption (or production) good, but because those who accept it expect it to be accepted in due course by someone else in a subsequent transaction. For such an arrangement to be feasible, we need at least three agents, with at least three items to be traded among them. For it to be efficient, moreover, a market in which the agents in question come together at one time and place to barter with one another at market clearing prices, must be, relatively speaking, "too costly" an alternative to organise and operate.

A number of attempts in modern literature to come to grips with these insights in terms of formal models have shown that what serves as the economy's means of exchange is fundamentally determined by the beliefs held by each agent about what will be accepted by other agents. ${ }^{1}$ The physical properties of a particular item - its durability, storability, portability, etc. - might affect the way in which those beliefs emerge, but in the last resort it is mutually consistent expectations, trust, that determines what functions as money.

These formal models nevertheless leave a lot to be desired in their current state of development. For example the environment in which monetary exchange emerges has isolated agents encountering one another at random as a result of an unsystematic search for trading partners - hardly a promising starting point for anyone seeking to explain the actual historical evolution of monetary systems - and the goods that are traded in the most widely cited model, that of Kiyotaki and Wright (1989), come in discrete units with their relative prices given, so that this model of money does not provide an explanation of the price level.

The central implication of this literature - namely, that any treatment of the individual agent's demand for money must pre-suppose the existence of monetary exchange, an arrangement 
that is underpinned by the mutually consistent beliefs of a group of agents, and is therefore properly characterised as a social institution - is nevertheless valid and important. A market experiment supporting monetary exchange is thus logically prior to the individual experiment supporting any agent's demand for money; and that market experiment is fundamentally non-Walrasian.

Walrasian foundations may nevertheless remain helpful in areas of economics where monetary questions are not central. An economy in which plans are coordinated by indirect exchange mediated by money could conceivably behave in many respects "as if" it were presided over by an auctioneer who maintains prices at market clearing levels and costlessly matches up buyers and sellers. Whether, in any particular application, it does so or not is an empirical question. To postulate the existence of a Walrasian market, while simultaneously forgetting that if this postulate is useful in the first place that is because a system of monetary exchange works "as if" a Walrasian market was operative, and then to ask how money might be introduced into a Walrasian market, is, however, to create a considerable intellectual tangle; but that is what much monetary economics has done in recent years.

One strand in recent literature imposes a "cash-in-advance" constraint upon an otherwise Walrasian system, and sometimes, in order to mimic the well known fact that empirical demand for money functions display interest-sensitivity, introduces a distinction between "cash goods" and "credit goods" as well. ${ }^{2}$ This approach does logically permit monetary issues to be discussed in an otherwise Walrasian framework, but the methodological objective of the New-classical research agenda that has sometimes adopted it was to derive results from so called "primitives": postulates about tastes, technology, endowments, and the rules of the Walrasian market. To supplement these primitives with an unmotivated rule about the conduct of market transactions is arbitrary, and does not sit well with the above-mentioned methodological objective. 
The alternative "overlapping generations" model of money is somewhat more appealing. ${ }^{3}$ It relies on a very special version of the insight that at least three goods and three agents, who cannot get together in the same time and place. are needed if money is to exist. The passage of time is of the essence here; goods are differentiated by their dating, and, given that agents live for two periods, "the social contrivance of money" enables indirect exchanges to take place between agents who can never meet, namely the current "old", and next period's "young". The former trade with the current "young", who when they become next period's "old", trade with the latter - and so on into the indefinite future.

There are, nevertheless, well known objections to this model as a basis for monetary theory. ${ }^{4}$ First, given its set-up, any durable asset, for example land, can serve to mediate intergenerational trade, and because money is held only in order to purchase future goods, if that durable asset is also productive, money will be rate of return dominated and not held at all, unless (a) a unit of money is itself a claim on a sufficient quantity of future goods - is "well backed" in the jargon of this literature, or (b) a "legal restriction" is arbitrarily imposed on the system that compels agents to hold money now and in the future. Absent at least one of these properties, the economy will find a "non-monetary" equilibrium, one in which money is valueless but in which. nevertheless, trade within each period is still carried on "as if" under the auspices of a Walrasian auctioneer.

In this approach, what is called "money" is in fact more akin to a store of value than to a means of exchange; and its characteristic prediction of an extremely high - in the limit infinite elasticity of demand for money with respect to the opportunity cost of holding it, is, in any event, empirically unsupported. 


\section{THE DEMAND FOR MONEY AND THE MEASUREMENT OF THE MONEY STOCK}

Given that an individual is a participant in an economy characterised by monetary exchange, the individual experiment that generates that agent's stock demand for money can be investigated along well known lines. "Transactions", "precautionary" and even "speculative" motives for holding money can be analysed, as can the capacity of an inventory of cash balances to help the agent holding it to economise on time devoted to "shopping"; and it might even be concluded that the results yielded by such analysis can be usefully approximated by treating money "as if" it were a durable good which yields an undefined, but nevertheless utility generating, flow of services.

The outcome of any individual experiment along these lines will be a demand function in which the dependent variable is a stock of real balances, and the independent variables include one or more "scale" variables - real income, real permanent income, real wealth, etc. - one or more opportunity cost variables - some nominal interest rate, the expected inflation rate, the own rate of retum on money, etc. - and, depending on the particular version of the individual experiment performed, a variety of other variables too - some measure of price level variability, perhaps, or of the value of the agent's time, etc.. It will, in short, be some version of what we call the long run demand for money function, which can be aggregated to the level of the whole economy, usually by postulating that the aggregate economy behaves "as if" it were scaled-up representative agent. 5

Such an aggregate relationship forms the basis of a market experiment, logically distinct from that underpinning monetary exchange, which has provided the starting point for a vast array of empirical studies. These have revealed a number of problems, three of which are of particular interest here. First, it is no trivial matter to decide just what is and is not "money" in any actual economy. Second, the long run function turns out to be too simple to deal with available data, except perhaps at a very high level of time aggregation. It needs to be supplemented with 
distributed lags in order to do so in a satisfactory fashion, thus producing, in older terminology, a short run function; or, to make the point in modern jargon, an error-correction mechanism is needed to supplement the co-integrating vector which characterises the long run function. ${ }^{6}$ Third, the demand for money, both short-run and long-run, has displayed a good deal of apparent instability over time.

The first and last of these problems have proved particularly troubling for policy makers, for obvious reasons, and that they are intimately related to one another has been the central message of the work of Barnett and his associates on the micro-foundations of the demand for money, whose basic insights may be described as follows. ${ }^{7}$ There is no sharp dichotomy between items which do and do not function as means of exchange; there is a spectrum of assets, some of which are more readily acceptable, or more readily and cheaply convertible into something acceptable, than others. To partition this spectrum into two subsets, to treat all assets falling into one of them as being perfect substitutes for one another, so that their simple sum aggregate provides an appropriate empirical representation of the quantity of money, is quite arbitrary. The microeconomic theory underlying superlative index numbers tells us that interest rate differentials among assets contain information about their relative "moneyness" which can be used to generate potentially more useful weighted monetary aggregates.

Furthermore, the real-world market experiment that supports the institution of monetary exchange and underlies the individual's demand for money does not repeat itself in an unchanging pattern over time. Rather, it evolves as human ingenuity is brought to bear on the provision of transactions services. This is not a new phenomenon: the invention of the chequable deposit, or the introduction of the clearing house, probably had just as much of an impact on the mechanisms of monetary exchange in their time as the application of computer technology is having nowadays. ${ }^{8}$ 
Nor are changes in this market experiment necessarily spontaneous: monetary systems are subject to regulation which varies over time.

Institutional change, whether driven by technology or regulation, can and does alter the relative "moneyness" of various assets, and the use of superlative index numbers to represent monetary aggregates captures these effects in a way that simple sum aggregation does not. A good deal of the instability that demand functions for simple sum monetary aggregates have recently displayed seems to have stemmed from this source, particularly from regulatory changes which tend to produce discrete steps in the relative moneyness of particular assets which in turn are quickly reflected in changes in their own rates of return.

Much work nevertheless remains to be done on questions of aggregation. In order to obtain a measure of any but the narrowest concept of money we do need to aggregate over assets, and superlative index numbers certainly help here; but to obtain an aggregate demand for money function we must also aggregate over heterogenous agents - households, manufacturing firms, financial firms, etc. - and the consequences of this for the stability of the economy-wide relationship remains under-investigated. There is also the matter of the implications of all this for the day to day conduct of monetary policy. If measures of the money stock are used only as indicators of the stance of policy, there presumably is no problem in adding superlative aggregates to the array of data to be consulted, but if the money stock is also to be used as an intermediate policy target, things are more complicated. How would one, for example, set about controlling the growth rate of Divisia M4? ${ }^{9}$

\section{MONEY AS A BUFFER STOCK}

The study which first drew attention to stability problems in aggregate demand for money 
functions was Goldfeld (1976), which dealt with a short-run relationship fitted to U.S. data. Some of these problems have, as Mizen notes, turned out to be consequences of the fact that the mere addition of a lagged dependent variable to a long-run function was too simple a device to capture the error-correction mechanisms driving fluctuations in the data around that underlying long run relationship.

These mechanisms could result from expectational phenomena and associated measurement error problems, or from a process of adjustment towards long run equilibrium caused by transactions costs of various sorts. These two approaches are not mutually exclusive, although if real world markets always maintained prices at market clearing levels, it would be necessary to rely on expectational effects alone. ${ }^{10}$ However, if we recall that the social institution of monetary exchange which underpins the demand for money function in the first place is an alternative to the Walrasian market which would accomplish this. it seems safe to assume that both expectational and adjustment mechanisms are of empirical relevance.

"Buffer-stock" models elaborate just this presumption. ${ }^{11}$ They start from the postulate that, in the individual experiment, the long run quantity of money demanded should be thought of. not as a given quantity of cash balances kept on hand at each and every moment, but as the average value of an inventory of cash balances about which actual holdings will fluctuate over time as the consequence of a stochastic element in the pattern of payments and receipts. ${ }^{12}$ Thus, the individual agent may be away from a steady state level of money holdings at any moment, without simultaneously being in disequilibrium in the sense of failing to carry out utility maximising plans.

The market experiment that follows from such an individual experiment raises more complicated issues. Note first that, if each agent is on his long run demand for money function on average over time, and if any one agent's stochastic payment is another's stochastic receipt, then, 
in the absence of any aggregate shock, the economy as a whole will be on its long run demand for money function at each and every moment. There are a number of ways in which such an aggregate steady state might nevertheless be disturbed. but here, for the sake of brevity, we shall consider only the consequences of a policy induced change in the nominal money supply, treating this variable first as exogenous and second as endogenous.

An exogenous increase in the nominal money supply will, in the absence of a Walrasian mechanism to maintain prices at their market clearing levels, initially create a level of money holdings in excess of the economy's long run demand. and agents will on average be away from their steady state money holdings; they will not be in disequilibrium, however, because from the typical individual's point of view, a random cash inflow in excess of disbursements has been encountered, an occurrence for which contingency plans to allow cash balances temporarily to rise, were already in place.

Even so, in the wake of an injection of cash into the economy, agents will on average find their cash balances remaining above their planned steady state levels, and as a result, again on average, will increase their planned and actual expenditures in order to eliminate this discrepancy. With an exogenous quantity of nominal money, however, the discrepancy can only be eliminated at the level of the economy as a whole if some argument or arguments in the long run demand for nominal money function change. In the usual set up, the requisite adjustment ultimately takes place in the price level.

During the transition period between steady states, all arguments in the demand for money function, including real income and interest rates as well as the price level, are likely to vary; and observed money holdings will therefore fluctuate around the co-integrating vector that describes the economy's long run demand for money function. In short, in this market experiment the adjustment 
mechanisms underlying what we call the "short-run" demand for money function will characterise some unspecified and ill understood quasi-reduced form of what is usually called the "transmission mechanism" of monetary policy. ${ }^{13}$ If we accept the conventional wisdom that this mechanism works with long and variable lags, and I know of no reason why we should not, then we should not be surprised by instability in the short-run demand for money function.

This is all well and good, but bank money is endogenous, and if too much of it is in circulation, its amount can be reduced by the return of some of it to the banking system, either in cancellation of debts or in exchange for other non-monetary assets. It is not immediately obvious, therefore, that conclusions established using a model in which money is exogenous can be carried over to one in which it is not. I shall now argue that they can, albeit in modified form, and that the amount of modification required is an empirical matter.

To say that the quantity of bank money is endogenous is not also to say that it is purely demand determined. Banks can only create money if they have willing borrowers to accept it, but agents do not always, or even usually, borrow from banks to increase their money holdings. Money is, as has repeatedly been stressed, a means of exchange, and more typically agents borrow money from a bank because, given the current structure of interest rates, including the implicit own rates of return on durable goods of various sorts, they wish to adjust their balance sheets by simultaneously increasing their bank debt and their holdings of durable goods. They require money to mediate the transactions involved, but the money created when an individual agent borrows from a bank is not permanently added to that agent's cash balances. Rather it is passed on to some other agent as a purchase is made.

Thus, when bank lending, and therefore the money supply increases, the economy experiences an initial increase in cash balances above its steady state demand for them just as it 
does in the exogenous money case. Thereafter, however, matters are more complex because when individual agents discover that their money holdings are, on average over time, remaining too high, they now have the option of reducing them, not only by increasing expenditure on goods and services, but also by transacting with the banking system.

It is vital to bear in mind the individual-market experiment distinction when thinking about these possibilities. The individual can get rid of unwanted cash by transacting either with the banking system or with another agent, but it is only the former act which also eliminates excess cash for the economy as a whole. Excess cash can remain in existence, therefore, not because any one agent irrationally continues to hold it, but because a series of agents each eliminate their own individual excess money holdings by passing them on to others in a sequence of market transactions. And such a sequence of transactions will in general have consequences for the value of arguments in the demand for money function, including, in the longer term, the price level. If, therefore, in the wake of an injection of bank money, transactions with other agents dominate, an economy which uses bank money will behave much like one in which nominal money is exogenous, and if transactions with the banking system dominate, it will approximate one in which nominal money is passively endogenous. ${ }^{14}$

At present, we know only a little empirically about this matter. Many studies, of which Jonson, Moses and Wymer (1976) is an early example, have uncovered a relationship between a divergence of the quantity of money from its desired level and subsequent expenditure flows, a relationship consistent with buffer stock mechanisms; and one recent study (Scott Hendry, 1995) of the demand for M1 in Canada bears directly on this issue, finding, first that there is a stable long run demand for this aggregate, and second that the error correction mechanism around the cointegrating vector that characterises this function involves variations in both the nominal quantity 
of money and the price level interacting to move real balances back towards their steady state value in the wake of disturbances. ${ }^{15}$ This result is, of course, quite consistent with the view that the short-run demand for money function, even in an endogenous-money economy, represents a quasireduced-form of the transmission mechanism linking monetary policy to the behaviour of the price level, a relationship in which instability might be expected to be of the essence.

\section{WHERE DO WE GO FROM HERE?}

A common theme runs through the issues raised in this essay, namely that in order to understand money, it is necessary to focus on its means of exchange role. The basic insight about the role of mutually consistent beliefs in supporting monetary exchange yielded by models like that of Kiyotaki and Wright (1989) is therefore important, even though such models seem capable neither of getting to grips with the historical emergence of money, nor of providing a link between the micro-foundations of monetary exchange per se and other phenomena with which we might want to deal, for example the explanation of variations in the purchasing power of money.

Here, an alternative line of argument, in which markets in specific goods and services (albeit not Walrasian markets) are created by specialised traders, and in which credit relationships emerge among agents who repeatedly transact with one another, seems promising. ${ }^{16}$ Credit arrangements are facilitated by a unit of account that is commonly used among those they link; and in such a set up it seems natural to think of a means of exchange emerging in the form of a portable reification of that unit of account as the scope of indirect exchange expands.

One important potential advantage of forging a theoretical link between money's unit of account and means of exchange functions lies in the fact that such a link seems essential if monetary theory is to provide an explanation of price level behaviour. ${ }^{17}$ Another is that, in an 
economy in which shoppers move among specialised traders who hold inventories of goods ready for sale at pre-posted prices, a buffer-stock demand for money on the part of both buyers and sellers will occur, thus providing an important link between the theory of money's origins and the theory of the individual agent's demand for it. Finally, Barnett's analysis of the microeconomics of aggregation should be ready applicable to the long run demand for money function that will characterise such an economy as the complexity of its financial system grows over time.

In conventional equilibrium economic analysis, equations describing agents' supply and demand functions for goods, services and assets are solved for an array of prices and quantities. The validity of this procedure rests on the implicit assumption that social arrangements that permit the plans of individuals to be rendered mutually compatible through price variation exist. Newclassical monetary economics in the spirit of Lucas (1972) reconciles such continuous co-ordination of plans with fluctuations in quantities of goods produced and traded by postulating that unanticipated shocks to the quantity of money lead to discrepancies between the actual structure of relative prices and agents' perception of them.

A satisfactory formulation of the approach to monetary economics broached in this essay, in which monetary exchange is an alternative institution to the Walrasian market, and in which prices are sticky, would follow a different route. ${ }^{18}$ Instead of focusing on discrepancies between actual and perceived prices, it would treat variations in cash holdings around their long run equilibrium levels, and also perhaps in traders' inventories of goods, as the key factors reconciling fluctuations in aggregate quantities produced and traded with the postulate that individual agents are nevertheless implementing their utility maximising plans.

Quantities of goods and services bought and sold in such a model would not necessarily be equal to quantities supplied and demanded. Individuals would nevertheless be properly 
characterised as merely executing plans already made for just such a contingency, namely permitting their precautionary inventories of cash and goods to absorb the consequences of shocks emanating from the market, prior to reformulating their future plans, which in the case of traders might involve changing posted prices.

\section{CONCLUDING COMMENT}

Currently prevailing orthodoxy in macroeconomics looks to Walrasian general equilibrium theory for its microeconomic foundations, and this has led to grave difficulties when it comes to the analysis of money. An alternative approach, which emphasises money's means of exchange function, and the role of monetary exchange as an alternative means of co-ordinating individual choices to those postulated by Walrasian analysis, underlies all the contributions to this symposium. That the approach in question has not yet achieved the degree of logical coherence that characterises prevailing orthodoxy may be treated either as a reason for rejecting it, or as a sign that there are likely to be significant pay-offs to investigating it further. It should go without saying that this author recommends the latter stance. 


\section{ENDNOTES}

1. See, e.g. Jones (1976) and Kiyotaki and Wright (1989), and note that Gravelle (forthcoming) has shown that this work harks back to ideas discussed by Carl Menger (1892), and Georg Simmel (1911), among others. See Selgin (1994) for a recent contribution to the literature which pays careful attention to its Austrian origins.

2. The cash-in-advance model originated with Clower (1967), who could hardly have been happy with its subsequent integration into Walrasian models. Svensson (1985) was responsible for introducing the cash-goods credit-goods distinction into this style of analysis.

3. See Lucas (1996) for a recent exposition of the case for using the overlapping generations model as the basis for monetary analysis.

4. McCallum (1983) remains an eloquent statement of the weaknesses of the overlapping generations approach to monetary theory.

5. For a useful survey of theories of the demand for money, see Goodfriend and McCallum (1987). Note that some precautionary demand models imply the possibility of interactions among individual agents' demand for money functions that would preclude such simple aggregation. On this, see Laidler (1990, Ch. 1, pp. 20-21).

6. See Keith Cuthbertson's contribution to this symposium for a discussion of some of the econometric issues involved here.

7. See Barnett's contribution to this symposium for a comprehensive list of references to the relevant literature.

8. See Jevons (1875) for a discussion of the influence of the then recently introduced innovation of the clearing house on the "mechanism of exchange" in the contemporary British economy.

9. Cuthbertson also raises this issue in his contribution to this symposium.

10. See Goodfriend (1985) for a particularly thorough exposition of such an approach.

11. As readers of Mizen's contribution to this symposium will immediately see, the label "bufferstock" is these days more properly attached to a family of models rather than any one framework. However, at the level of the individual experiment, it is probably fair to characterise all members of this family as being linked by a common descent from models of the precautionary demand for money.

12. It is worth noting that Alfred Marshall long ago defined the demand for money as just such an average value. See Marshall (1871).

13. On this matter, see Laidler (1982, Ch. 3) and (1990, Chs. 1, 2 and 5). 
14. For a formal analysis of the processes at work here, see Davidson and Ireland (1990). Laidler and Robson (1994) provide a less formal discussion of the issues involved.

15. See also Marcel Kasumovitch (1996) who presents empirical evidence that both policy induced interest rate changes and the variations in the quantity of money which they engender have distinct effects on expenditure flows, a result that is consistent with the extension of the buffer-stock market experiment to the endogenous (though not passively so) case.

16. This approach has appeared in one form or another in recent contributions by Hicks (1989), Clower (1994), Howitt (1994) and Ascheim and Tavlas (1996), and it also plays an important role in post-Keynesian analysis (e.g. Wray 1990), as June Flanders (1996) points out.

17. Closely related, models which forge such an explicit theoretical link between these functions of money are also helpful in understanding the feasibility of monetary arrangements which seek to separate them. See Yeager (1985) for a succinct discussion of some of these issues, along with references to relevant literature.

18. The reasons why one might expect price stickiness to arise in a world characterised by monetary exchange rather than Walrasian markets are discussed, along with references to earlier literature on this topic, in Laidler (1990, Ch. 1, pp. 9-17), while the role of buffer stocks of money in permitting individuals to carry out their plans in markets where discrepancies between supplies and demands for goods can emerge is discussed in Laidler (1990, Ch. 5, p. 84). 


\section{REFERENCES}

Ascheim J. and Tavlas G. (1996) "Monetary Economics in Doctrinal Perspective - Review Essay," Journal of Money, Credit and Banking, 28 (August), pp. 406-417.

Barnett W.A. (199*) "Which Road Leads to Stable Money Demand?", Economic Journal, (this issue).

Clower R.W. (1967) "A Reconsideration of the Microfoundations of Monetary Theory," Western Economic Journal, 6 (December), pp. 1-8.

(1995) "On the Origins of Monetary Exchange," Economic Inquiry, 33 (October) pp. 525-536

Cuthbertson K. (199*) "Microfoundations and the Demand for Money," Economic Journal, (this issue).

Davidson J. and Ireland J. (1990) "Buffer Stocks, Credit, and Aggregation Effects in the Demand for Broad Money: Theory and an Application to the U.K. Personal Sector," Journal of Policy Modelling, 12 (Summer), pp. 349-376.

Flanders J. (1996) "Left and Right Endogenous Money," London, Ontario, The University of Western Ontario, Department of Economics (mimeo).

Goldfeld, S. M. (1976) "The Case of the Missing Money," Brookings Papers on Economic Activity (3), pp. 683-730.

Goodfriend M. (1985) "Reinterpreting Money Demand Regressions" in K. Brunner and A.H. Meltzer (eds.), Understanding Monetary Regimes, (Carnegie Rochester Conferences Series on Public Policy, Vol. 22) Amsterdam, North Holland.

and McCallum B.T. (1987) "Demand for Money - Theory" in J. Eatwell, M. Milgate and P. Newman (eds.), The New Palgrave: a Dictionary of Economics, London, Macmillan.

Gravelle T. (forthcoming) "What is Old is New Again," Manchester School.

Hendry S. (1995) "Long Run Demand for M1," Working Paper 95-11, Ottawa, Bank of Canada.

Hicks J.R. (1989) A Market Theory of Money, London, Oxford University Press.

Howitt P.W. (1994) "Cash in Advance, Micro-foundations in Retreat," London, Ontario, The University of Western Ontario, Department of Economics, mimeo.

Jevons W.S. (1875) Money and the Mechanism of Exchange, London, P.S. King. 
Jones R.A. (1976) "The Origin and Development of Media of Exchange," Journal of Political Economy, 84 (August), pp. 757-775.

Jonson P.D., Moses E. and Wymer C.R. (1976) "A Minimal Model of the Australian Economy," Discussion Paper 7601, Sydney, Reserve Bank of Australia.

Kasumovitch M. (1996) "Interpreting Money-Supply and Interest-Rate Shocks as Monetary-Policy Shocks," Working Paper 96-8, Ottawa. Bank of Canada.

Kiyotaki N. and Wright R. (1989) "On Money as a Medium of Exchange," Journal of Political Economy, 97 (August), pp. 927-954.

Laidler D. (1982) Monetarist Perspectives, Oxford, Philip Allan.

(1990) Taking Money Seriously, Hemel Hempstead. Philip Allan.

and Robson W.B.P. (1994) "Endogenous Buffer Stock Money in Bank of Canada." Credit, Interest Rate Spreads and the Monetary Policy Transmission Mechanism, Ottawa, Bank of Canada.

Lucas R. E. Jr. (1972) "Expectations and the Neutrality of Money," Journal of Economic Theory, 4 (April), pp. 103-124.

(1996) "Nobel Lecture: Monetary Neutrality," Journal of Political Economy, 104 (August), pp. 661-682.

Marshall A. (1871) "Money" in J. Whitaker (ed.) (1975), The Early Economic Writings of Alfred Marshall, London, Macmillan.

McCallum B.T. (1983) "The Role of Overlapping Generations Models in Monetary Economics in K. Brunner and A.H. Meltzer (eds.), Money, Monetary Policy and Financial Institutions (Carnegie-Rochester Conference Series on Monetary Policy Vol. 18), Amsterdam, North Holland.

Menger C. (1892) "On the Origin of Money," Economic Journal, 2 (1), pp. 239-255.

Mizen P. (199*) "Microfoundations for a Stable Demand for Money Function," Economic Journal (this issue).

Patinkin D. (1957) Money, Interest and Prices, New York, Harper Row.

Selgin G. (1994) "On Assuring the Acceptability of a New Fiat Money," Journal of Money, Credit and Banking, 26 (November), pp. 808-826.

Simmel G. (1907) The Philosophy of Money (tr. T. Bottomore and D. Frisby), London, Routledge 
Simmel G. (1907) The Philosophy of Money (tr. T. Bottomore and D. Frisby), London, Routledge and Kegan Paul.

Svensson L.E.O. (1985) "Money and Asset Prices in a Cash-in-Advance Economy," Journal of Political Economy, 93 (October), pp. 919-944.

Wray L.R. (1990) Money and Credit in Capitalist Economies: The Endogenous Money Approach, Aldershot, Edward Elgar.

Yeager L. (1985) "Deregulation and Monetary Reform," American Economic Review, 75 (May), Papers and Proceedings, pp. 103-107. 